\title{
O CONCEITO DE
}

"LETRAMENTO" COMO

FONTE DE EQUÍVOCOS E

ERROS CONCEITUAIS

EM ALFABETIZAÇÃO

João Batista Araujo e OLIVEIRA (DD

do Instituto Alfa e Beto

Pedro Zany CALDEIRA (iD

Universidade Federal do Triângulo Mineiro (UFTM)

ఠ

OPEN ACCESS

EDITORES

- Miguel Oliveira, Jr. (UFAL)

- René Almeida (UFS)

AVALIADORES

- Eduardo Calil (UFAL)

- José Morais (ULB)

SOBRE OS AUTORES

- João Batista Araujo e Oliveira

Concepção, Escrita - Rascunho

Original, Escrita - Análise e Edição.

- Pedro Zany Caldeira

Concepção, Escrita - Rascunho

Original, Escrita - Análise e Edição.

DATAS

- Recebido: 20/10/2020

- Aceito: 11/02/2021

- Publicado: 15/05/2021

\section{COMO CITAR}

OLIVEIRA, J.B.A.; CALDEIRA, P.Z. (2021). O conceito de "letramento" como fonte de equívocos e erros conceituais em alfabetização. Cadernos de Linguística, v. 2, n. 1, p. 01-29.

\section{RESUMO}

Neste artigo, os autores exploram os equívocos e os erros conceituais que sistematicamente baseiam o discurso e as narrativas das políticas públicas e das propostas pedagógicas desenvolvidas no Brasil relacionadas à alfabetização com base no conceito de letramento. São identificadas duas fontes de equívocos e erros conceituais em alfabetização no Brasil e no mundo. A primeira é a "Whole Language", desenvolvida por Kenneth Goodman e explorada para efeitos de alfabetização por Frank Smith, e a segunda é a abordagem socioconstrutivista proposta por Emília Ferreiro para a aprendizagem da língua escrita. Essas fontes de equívocos e erros conceituais foram identificadas com especial vigor por Marilyn Adams em 1990 e definitivamente desmontadas pelo National Reading Panel em 2000. Contudo, a formação de professores alfabetizadores continuou a privilegiar essas abordagens, com profundas consequências nos níveis de alfabetização dos alunos. A situação é mais séria no Brasil, pois os documentos oficiais durante décadas propuseram processos de alfabetização sem base em qualquer evidência científica, abusando claramente da linguagem. No Brasil, os conceitos equivocados sobre o que é Aprender a Ler e Ler para Aprender, o impacto da aprendizagem 
mecânica nos processos de aprender a ler e escrever e a quase completa ausência de consideração das estruturas neuro-anatômicas nos processos de alfabetização impuseram metodologias de alfabetização também elas equivocadas que dificultam a aprendizagem das "primeiras letras". Estudos em neurociências esclarecem que os métodos fônicos são os únicos que proporcionam bons processos de alfabetização, ao estimularem as áreas cerebrais especializadas no processamento da linguagem lida e escrita.

\section{ABSTRACT}

In this article, the authors explore the mistakes and conceptual errors that systematically support the discourse and narratives of public policies and pedagogical proposals developed in Brazil related to literacy. Two major sources of misunderstandings and conceptual errors in literacy are identified in Brazil and worldwide. The first is "Whole Language", developed by Kenneth Goodman and explored for literacy purposes by Frank Smith, and the second is the socio-constructivist approach proposed by Emilia Ferrero for learning written language. These sources of misunderstandings and conceptual errors were identified with special vigor by Marilyn Adams in 1990, and definitively dismantled by the National Reading Panel in 2000. However, the training of literacy teachers continued to privilege "Whole Language" and socio-constructivism, with profound consequences on students' literacy levels. The situation is even more serious in Brazil, as official documents for decades have proposed literacy processes without any scientific evidence, wrote with a clearly abusing language and without strong literacy concepts. In Brazil, the misconceptions about Learning to Read and Reading to Learn, the impact of mechanical learning on the processes of learning to read and write and the almost complete absence and consideration of neuroanatomical structures in literacy processes enforced literacy methodologies that are also mistaken, that played more of a barrier role in learning the "first letters". Neuroscience studies clarify that phonic methods are the only ones that provide good literacy processes, as they stimulate brain areas specialized in the processing of read and written language.

\section{PALAVRAS-CHAVE}

Equívocos Conceituais; Erros Conceituais; Alfabetização; Abuso de Linguagem; Método Fônico.

KEYWORDS

Misconceptions; Errors; Literacy; Language Abuse; Phonics. 


\section{INTRODUÇÃO}

Este artigo tem como objetivo analisar o discurso subjacente às propostas de alfabetização que dominaram o panorama educacional brasileiro desde a década de noventa. $\mathrm{O}$ foco do artigo é na análise dos discursos e das narrativas desenvolvidas para fundamentar políticas públicas ou propostas pedagógicas relacionadas à alfabetização. Nos países desenvolvidos o conceito de alfabetização esteve sendo associado como parte do conceito mais amplo de literacia, definido como "tudo aquilo que, no indivíduo ou na cultura a qual pertence, resulta, resultou ou pode resultar direta ou indiretamente do desenvolvimento e uso da tecnologia da escrita." (KOLINSKY; MORAIS, 2014, p. 322). Esta definição, embora ampla, enfatiza a relação fundamental de dependência da leitura à escrita. No Brasil, o conceito de literacia só recentemente começa a entrar no vocabulário educacional, pelo que a discussão sobre alfabetização analisada no presente estudo sempre esteve associada ao conceito de "letramento".

De modo a facilitar a compreensão de seus argumentos, dividimos o artigo em duas partes: na Parte I, analisamos algumas características do discurso associadas ao conceito de alfabetização. A análise aponta para os erros conceituais, deslocamento de conceitos e usos inadequados da linguagem que estiveram associados à desconstrução do conceito de alfabetização e à sua substituição, no Brasil, pelo conceito de letramento. Assim, a primeira parte se concentra na questão da alfabetização e; na Parte II, analisamos o discurso utilizado pelos proponentes do conceito de letramento, documentando, em detalhe, os vícios de linguagem e os procedimentos de manipulação de conceitos e da linguagem associados a esse discurso, tendo o cuidado de apresentar evidências dos métodos de alfabetização que resultam ou não em bons processos de alfabetização.

\section{PARTE I - ERROS E CONCEITOS EQUIVOCADOS EM ALFABETIZAÇÃO}

As políticas e práticas de alfabetização, no Brasil e em diversos outros países, foram prejudicadas pela disseminação de erros conceituais, conceitos equivocados e abuso da linguagem utilizados por adeptos de concepções de alfabetização que divergem das práticas usuais do discurso e do debate científico dessa área (ver, por exemplo, MORAIS, 2014).

Os erros conceituais incluídos nessas concepções de alfabetização se apoiam em dois pilares distintos. Um deles deriva da área de psicolinguística, tendo como protagonistas Kenneth Goodman (1986) e Frank Smith (2003), que retomou e ampliou as ideias de Goodman e liderou uma corrente de ensino da língua que se tornou conhecida 
no mundo anglo-saxão como "Whole language" ou linguagem total. O outro erro conceitual deriva da área da psicologia e se baseia na publicação de Emília Ferreiro e Ana Teberovsky (1985), intitulada "Psicogênese da Língua Escrita", que deu origem ao que se denominou de "construtivismo" nos países de tradição latina e assumiu contornos específicos no Brasil sob o conceito de "letramento". Ambos tiveram um devastador impacto sobre as políticas e práticas de alfabetização nos diversos países do mundo, conforme divulgado por Oliveira (2018) em "Fraturas na Base: Fragilidades estruturais da BNCC - a Base Nacional Curricular Comum.

A ciência 'normal' (KHUN, 2017) avança identificando erros nos trabalhos já publicados e cometendo outros, que serão corrigidos pelas próximas gerações. Desde a década de 1980, nos Estados Unidos, esses erros relacionados à alfabetização começaram a ser identificados, tendo culminado com publicações de enorme repercussão não apenas no domínio científico (ADAMS, 1990) como também no que diz respeito à reformulação de políticas públicas, como foi o caso do National Reading Panel Report, no ano 2000. Uma revisão dessa literatura e das mudanças de políticas de alfabetização e seu impacto em diversos outros países encontram-se no relatório já citado (OLIVEIRA, 2018).

Um outro estudo liderado pela Academia Brasileira de Ciências (2009) também atualizou as evidências científicas e incorporou novas evidências especialmente associadas ao desenvolvimento da consciência fonológica e fonêmica em pré-escolares e aos impactos negativos de atrasar o processo de alfabetização.

Identificar a origem desses erros e analisar como o uso indevido da linguagem contribuiu para sua disseminação tanto nos meios acadêmicos quanto nas políticas públicas definidas pelo Ministério da Educação, especialmente nos documentos dos Parâmetros Curriculares Nacionais, em 1997 (BRASIL, 1997) ou nos documentos relacionados com as políticas de Alfabetização na ldade Certa (BRASIL, 2017), é crucial para melhor se compreender a sua gênese e a forma como se disseminaram e em alguns casos ainda prevalecem em documentos oficiais. Por exemplo, esses erros, equívocos e ambiguidades ainda se encontram presentes - embora com menor ênfase - em documentos como a Base Nacional Comum Curricular - BNCC (BRASIL, 2018), conforme destacado em Oliveira (2018).

No ano de 2019, a principal fonte de divulgação desses erros - o Ministério da Educação - começou a rever sua posição. Isso foi fundamentado com a divulgação do documento intitulado Plano Nacional de Alfabetização na Idade Certa (BRASIL, 2017), pela Secretaria de Alfabetização do MEC (SEALF). Pela primeira vez, desde os PCNs, os Parâmetros Nacionais Curriculares, o Ministério da Educação ouviu um grupo qualificado de cientistas e se apoiou nas evidências científicas já disponíveis desde o final do século passado para traçar diretrizes e orientar as políticas e práticas de alfabetização no país. 
Há um duplo objetivo nesta Parte do artigo. O primeiro é o de analisar a origem e o desenvolvimento das noções equivocadas. O segundo é o de servir de alerta para cientistas, pesquisadores e formuladores de políticas públicas a respeito da fragilidade e da fugacidade das "verdades" e das "evidências" científicas. Verdades científicas são fugazes, evidências raramente são clarividências. Todavia, é sobre elas que se apoia o fazer científico: ignorá-las, manipulá-las, silenciá-las ou negá-las não apenas viola as regras do jogo, mas pode trazer consequências perversas - como ocorreu no caso da alfabetização em vários países e muito especialmente no nosso. O alerta vale de modo particular para os especialistas em linguística - daí porque chamamos aqui a atenção de modo especial para os perigos dos abusos no uso da linguagem.

O avanço científico se dá pela acumulação de conhecimentos, mais do que por rupturas ou revoluções (KHUN, 2017). Mais pela especificação das assertivas do que pela introdução de assertivas radicalmente novas ou revolucionárias, conforme argumentado exaustivamente por Popper (1993). A "ciência" não é um conjunto consolidado e estático de axiomas normativos. Muito menos é obra de um ator ou de uma mão invisível. Ciência é a resultante do produto de cientistas em ação: cada cientista aponta os erros de seus antecessores ao vislumbrar novas perspectivas ou nuanças (MORAIS; KOLINSKY, 2020). Não há nem deve haver nada de errado ou de incômodo com esse processo.

Contudo, no caso, não se trata de uma linguagem científica, que poderia ser refutada pelos procedimentos usais: as propostas associadas ao conceito de letramento, do Brasil, que se utilizam de uma linguagem pseudocientífica. Essas, pois, desprovidas e dissociadas de evidências empíricas são utilizadas para se afirmar como paradigma ou marco conceitual que virtualmente monopolizou o discurso sobre alfabetização no país.

O presente artigo procura lançar luz exatamente sobre as nuanças e as manipulações de linguagem que contribuíram - e ainda contribuem - para disseminar erros e conceitos equivocados a respeito da alfabetização. Assim fazendo, pretendemos mostrar como a Ciência Cognitiva da Leitura e a psicolinguística oferecem subsídios para uma compreensão mais profunda sobre os processos neurocognitivos envolvidos nas etapas iniciais da aprendizagem da leitura e da escrita. Essas contribuições, por sua vez, apontam para a superioridade de um método de alfabetização em relação a outros. Contudo, para avançar, primeiro é necessário desfazer os erros e os equívocos que ainda predominam no imaginário e no vocabulário do establishment educacional do país.

\subsection{ERROS E CONCEPÇÕES EQUIVOCADAS NA FILOSOFIA, NAS CIÊNCIAS E NA MATEMÁTICA}

Erros e concepções equivocadas ocorrem não apenas entre os cientistas, mas também entre as pessoas comuns. As crianças chegam à escola com várias experiências e intuições corretas a respeito do mundo - de outra forma não conseguiriam sobreviver. Mas também 
chegam - e, frequentemente, permanecem e saem da escola - cometendo erros e mantendo inúmeras concepções equivocadas a respeito do funcionamento do mundo. Isso é especialmente comum nas áreas de Matemática e de Ciências. Felizmente, muitos desses erros não têm consequências práticas funestas - as crianças acreditam que as plantas se nutrem do solo, mas mesmo quando são expostas a um novo conhecimento não deixam de regá-las, o que é essencial para a sobrevivência delas. Distinguir entre erros e concepções equivocadas será útil para a nossa discussão posterior.

Erros na ciência e na linguagem derivam de concepções filosóficas mais fundamentais sobre a ciência e a linguagem. É evidente que pequenos erros iniciais levam a sérias consequências no final. Essas consequências não permanecem limitadas ao campo do discurso, pois afetam nosso entendimento a respeito de nós mesmos, nossas vidas, nossas instituições e nossa experiência - como por exemplo conceitos a respeito de padrões universais de comportamento, direitos naturais ou o conceito de felicidade, temas estudados no magistral ensaio de Mortimer Adler (1985) sobre equívocos e erros conceituais.

Na mesma direção, Henry David Thoreau (2016) já alertara para a importância do espírito necessário para compreender um texto verdadeiro:

\footnotetext{
... Ler bem, isto é, ler livros verdadeiros com espírito verdadeiro, é um exercício nobre, e que exigirá do leitor mais do que qualquer exercício valorizado pelos costumes do momento. Requer um treino como o dos atletas, a dedicação constante quase da vida toda a esse objetivo. Os livros devem ser lidos com a deliberação e a reserva com que foram escritos... (THOREAU, 2016).
}

Em seguida, tratamos de distinguir os conceitos de erro e concepções equivocadas comuns na aprendizagem escolar e, mais tarde, aplicaremos esses conceitos ao objeto específico do presente trabalho.

\section{Erros}

Erros são mais fáceis de detectar e de corrigir. Por exemplo, podemos errar ao realizar uma operação simples de adição. Isso pode refletir falta de conhecimento, atenção ou prática. Por exemplo, um erro de adição:

\begin{tabular}{|r|r|}
\hline & 52 \\
\hline+ & 46 \\
\hline & 96 \\
\hline
\end{tabular}

\section{Concepções equivocadas}

Considere o exemplo abaixo:

\begin{tabular}{|r|r|}
\hline & 28 \\
\hline+ & 56 \\
\hline & 714 \\
\hline
\end{tabular}


O caso ilustra uma concepção equivocada sobre o conceito de "vai um". O aluno registra o 1 e ao invés de obter 84 ele obtém 7, 1, 4 - o que revela um entendimento equivocado do sistema decimal ou do "quadro valor lugar".

No estudo das Ciências, no ambiente escolar, são comuns concepções equivocadas como: o Sol nasce no Leste e se põe no Oeste, plantas obtêm alimento do solo, as partículas se expandem quando são aquecidas ou a luz viaja dos olhos ao objeto.

Há uma sólida literatura a respeito de concepções equivocadas no ensino de Ciências, como por exemplo em Chi (2008), Ohlsson (2009), Sadler, Sonner, Coyle, Cook-Smith e Miller (2013), Barke, Hazari e Yitbarek (2009) e Talanquer (2007) na Química. Inicialmente denominadas de "misconceptions" (WANDERSEE; MINTZES; NOVAK, 1994) essas ideias também foram estudadas sob o nome de "concepções ingênuas" (CHINN; BREWER, 1993), "conhecimento intuitivo" (VOSNIADOU; IOANNIDES; DIMITRAKPOULOU; PAPADEMETRIOU, 2001) "primitivos epistemológicos" ou "p-prims" (DISESSA, 1993; MINSTRELL, 1992). Também foram estudadas sob o nome de "quadros de referência alternativos" (CAREY; EVANS; HONDA; JAY; UNGER, 1989). Independentemente da terminologia, esses estudos mostram que o conhecimento prévio de um aluno está embebido em algum tipo de lógica ou mesmo racionalidade, mesmo quando é incompatível com o conhecimento científico estabelecido (TOMITA, 2008, p. 10).

Rosalind Driver com seus colaboradores (2008) e Driver, Squires, Rushworth e WoodRobinson (1994) fizeram enormes contribuições para o entendimento das concepções científicas equivocadas dos alunos. De acordo com essas autoras, esses equívocos derivam das observações e interações dos alunos com seus colegas e se baseiam no "senso comum", porém, em lógicas equivocadas. Os alunos não possuem clareza a respeito do que é relevante e que precisa ser objeto de atenção e de foco. Nutrem preconcepções a respeito do eventual resultado de um experimento (a fumaça se move no ar de maneira aleatória) e possuem falta de clareza a respeito de convenções científicas (por exemplo, uma seta pode se referir: a uma força, em física; à transferência de energia, em biologia; à mudança de reagente a produtos, na química).

Yip (1998) foi um dos primeiros a identificar a prevalência e transmissão de concepções equivocadas por professores de química. Já Sadler et al. (2013) documentam a relação entre a falta de conhecimentos dos professores e os resultados dos alunos. Nesse estudo, o nível de conhecimento dos professores era bastante elevado e semelhante, com cerca de $84 \%$ de acertos em média. Mas seu conhecimento a respeito dos erros de concepção de conceitos científicos pelos alunos era muito baixo - apenas $43 \%$ de acertos. Os itens utilizados para testar os professores foram previamente verificados com alunos do Ensino Médio, para se identificar os seus tipos de concepções. As análises dos autores concluem que o efeito do professor é diferente de acordo com o nível dos alunos e com a existência ou não de "misconceptions", ou concepções equivocadas: em geral, os alunos aprendem 
mais quando os professores conhecem os conteúdos e estão conscientes das concepções equivocadas dos alunos.

Não obstante, para isso, os professores também precisam estar isentos das concepções equivocadas, pois o estudo também mostra que os estudantes de baixo nível acadêmico são os que menos aprendem quando o professor carece de conhecimentos sobre a existência e a origem dessas concepções equivocadas. As concepções equivocadas podem existir relativamente a qualquer área do conhecimento e tanto professores como alunos podem ter esse tipo de concepções. Por exemplo, estudo publicado por Oliveira (2012) revela que menos de 50\% dos professores sabiam identificar o sistema de escrita da Língua Portuguesa.

Essa literatura também apresenta sugestões a respeito de como superar esses erros e concepções equivocadas. O primeiro passo é começar com a visão científica correta. Uma vez introduzido o conceito, torna-se possível apresentar as visões equivocadas, demonstrando porque elas são erradas ou equivocadas, apresentando teorias competitivas para que o indivíduo seja capaz de rejeitá-las à luz das evidências. Um segundo passo consiste em criar um conflito cognitivo como estratégia para promover a reorganização das ideias.

Essa foi a estratégia utilizada nos Estados Unidos e que resultou na publicação do livro de Marilyn Adams (1990) intitulado "Beginning to Read: Thinking and Learning About Print". Passaram-se mais 10 anos de intensos debates até que a publicação do Relatório do National Reading Panel (2000) pôs um final nos debates. Desde essa época, as ideias do "Whole Language", que já vinham perdendo terreno, deixaram de influenciar as políticas públicas e grande parte das práticas de alfabetização. Todavia, mesmo nos Estados Unidos, as faculdades de educação continuaram a ignorar as evidências (GAUTHIER, BISSONNETTE, RICHARD, 2010) e persistiram a privilegiar modelos equivocados gerados por autores que Seidenberg (2017), ironicamente, designa de "zumbis teóricos", pois alimentam-se de estudantes e de professores, 'infectando-os' com conceitos errôneos ou equivocados (CALDEIRA, BOSSLER, no prelo). Movimentos semelhantes ocorreram na França, com a criação do Observatório Nacional da Leitura, e na Inglaterra, com a edição de sucessivos "White Papers", revendo essas questões. Desde o início do século, apesar de focos de resistência, não há registro de publicações em revistas científicas com comitês editoriais rigorosos que contestem essas evidências.

No Brasil, a disseminação desses erros não se deu por meio de um debate acadêmico e apresentação de evidências. O único trabalho apresentado foi o livro de Emília Ferreiro e Ana Teberovsky (1985), cuja argumentação foi devidamente desconstruída por Andrade, Andrade e Prado (2017). Ao contrário, a disseminação se deu por meio de documentos oficiais do Ministério da Educação e de publicações de centros universitários, notadamente - CEALE, na Universidade Federal de Minas Gerais. E, especialmente, pela imposição de 
programas oficiais como o Alfabetização na Idade Certa e do Programa Nacional do Livro Didático (PNLD), que acabaram consagrando esses equívocos como modelo único a ser seguido em todo o país, apesar da sua falta de cientificidade.

Esse modelo único necessita ser estripado, trazendo à luz as suas entranhas - e os equívocos - constantes do discurso acadêmico e oficial associado à desconstrução do termo "alfabetização" e sua substituição pelo termo "letramento". Palavras são armas e as armas do letramento tiveram efeito funesto sobre as políticas e práticas de alfabetização no Brasil, conforme sobejamente constatado até mesmo por testes oficiais de desempenho dos alunos.

\subsection{EXEMPLOS DE ERROS E CONCEPÇÕES EQUIVOCADAS SOBRE O CONCEITO DE ALFABETIZAÇÃO}

Passamos a apresentar alguns exemplos de erros e concepções equivocadas sobre o conceito de "alfabetização". O objetivo é caracterizar a variedade de formas e de usos inadequados da linguagem para promover ideias sem fundamento científico.

\subsection{1. “WHOLE LANGUAGE”: UM EXEMPLO DE ERRO CONCEITUAL/EMPÍRICO}

As ideias fundantes do movimento conhecido como "Whole Language" foram desenvolvidas inicialmente por Kenneth Goodman (1986), que se inspirou na primeira proposta de Chomsky sobre a natureza da linguagem oral. Frank Smith (2003) se apropriou delas e as expandiu para a área da aprendizagem da língua escrita.

Kenneth Goodman (1965) se apoiou em um único estudo empírico realizado com 30 crianças cujas replicações por outros cientistas não levaram aos mesmos resultados (ANDRADE et al., 2017) para desenvolver o seu modelo. Ou seja, foi ancorado num experimento sem validade científica e numa interpretação equivocada de seus resultados que Frank Smith propôs as ideias que se tornaram tão populares desde os anos 70 . Em síntese, ele afirma que: (a) o texto é uma variedade da linguagem, algo natural e que (b) portanto (grifo nosso) deve ser aprendido naturalmente. As letras, o processo de decodificá-las e a leitura individual de palavras atrapalha o processo de compreensão.

Segundo esta formulação, os "bons leitores" não leem palavras, eles captam o sentido pelo contexto. Em termos genéricos, essa caracterização dos "bons leitores" está completamente equivocada; pois, os "bons leitores" antes de o serem são "maus leitores", titubeiam inicialmente na leitura de palavras pequenas, que rapidamente assimilam passando-as para o seu "vocabulário à vista" e passam a titubear na leitura de palavras plurissilábicas, que anteriormente não conseguiam ler. A incompreensão de Frank Smith sobre a gradualização desse processo de "tornar-se leitor", que nada tem de adivinhação a 
partir de pistas contextuais, está na base de todos os posteriores equívocos sobre o processo de aprendizagem da leitura.

Como é próprio do processo científico, Frank Smith reagia às ideias prevalentes na época, especialmente associadas ao behaviorismo e ao associativismo. O novo foco passou a ser a compreensão - e com isso o processo de "leitura" foi ignorado. Somente alguns anos mais tarde, os estudos de Perfetti, van Dyck e Hart (2001) e de Stanovich (1986) comprovaram empiricamente que os bons leitores leem todas as palavras (e letras) do texto e que, afinal, são os maus leitores que se apoiam no contexto para interpretar palavras e frases. Posteriormente, outros estudos, como os de Gombert (2003), demonstraram que o cérebro também mobiliza e identifica elementos menores das palavras - como prefixos e sufixos - para identificar as palavras e o seu sentido. No entanto, passaram-se pelo menos vinte anos até que essas ideias fossem efetivamente reconhecidas pela comunidade acadêmica, nos Estados Unidos; sendo que o caminho das pedras nessa área está bem mais duradouro no Brasil.

Trata-se, assim, de um tipo de erro comum na evolução da ciência. Um erro que serviu de base para o desenvolvimento e a disseminação das ideias da "psicogênese". Um tipo de erro que pode ser identificado e superado com evidências empíricas. Isso, no entanto, não minimiza o estrago que esse erro causou e infelizmente ainda causam nas políticas e práticas da alfabetização no nosso país.

\subsubsection{DESLOCAMENTO DE CONCEITOS}

O outro tipo de erro cometido por Kenneth Goodman refere-se ao deslocamento de conceitos: um conceito desenvolvido numa área (linguagem oral) foi transportado para outra (escrita).

Na língua inglesa, se usam os termos (mis)placement e (dis)placement para indicar quando um descolamento pode ou não ser correto. Donald Schon (1963) sugere uma interpretação benigna para acolher o conceito de (dis)placement de conceitos. Ele compara o "deslocamento" de conceitos como um tipo de analogia ou metáfora e, nessa perspectiva, o deslocamento constitui um mecanismo saudável e necessário, pois permite transpor uma teoria velha para uma nova, reinterpretar uma nova situação ou possibilitar a aplicação de um conceito (ou metáfora) a uma nova situação.

No caso da alfabetização, no entanto, deparamo-nos com duas instâncias de "misplacement", tanto no caso de Kenneth Goodman / Frank Smith quanto no caso de Emília Ferreiro e Ana Teberovsky.

Comecemos por Goodman. Há elementos científicos - hoje mais do que na época em que Chomsky formulou a primeira versão de sua teoria - para identificar aspectos inatos da fala, da comunicação e da compreensão de conceitos. Mesmo entre os animais, esses 
tais mecanismos podem ser identificados, pois a fala e a comunicação constituem parte de nosso arsenal de sobrevivência. Porém, não há qualquer elemento científico que justifique aplicar o mesmo conceito à escrita - pois esta é uma invenção e, ademais, uma invenção relativamente recente com tempo insuficiente para ter provocado uma adaptação, muito mais uma mutação genética (DEHAENE, 2012).

Além disso, os estudos mais recentes sugerem expressamente que o formato das letras/ ideogramas atuais não são de fato totalmente aleatórios, pois são formatos facilmente identificados pelas regiões cerebrais de reconhecimento de padrões essenciais para a sobrevivência da espécie (DEHAENE, 2020). Parece, deste modo, que o ser humano usou as ferramentas neuro-anatômicas que já tinha disponíveis para inventar a escrita. $\mathrm{O}$ equívoco de Goodman, inspirado em Chomsky, é postular a existência de um equipamento inato para a aquisição da linguagem que seria transferível para a aquisição da leitura e que, assim, a leitura deveria ser aprendida de forma tão natural quanto a fala.

Emília Ferreiro também incorre em outro tipo de "mis-placement", a partir do uso (indevido) do termo "psicogênese" aplicado à Língua Escrita. O próprio termo "psicogênese" denuncia a origem do equívoco. O conceito de psicogênese havia sido desenvolvido por Piaget na tentativa de explicar a evolução dos processos mentais. Piaget tinha formação filosófica e científica. Sua formação filosófica era kantiana - e com isso não podia admitir a pré-existência de conhecimentos na mente, no entanto, admitia a possibilidade de categorias pré-existentes ao conhecimento propriamente dito. A sua formação científica como biólogo também o impelia a enxergar a força da natureza. Disso resultou sua "epistemologia genética" - segundo a qual o ser humano nasce com a capacidade de conhecer, mas os conhecimentos são construídos pela mente. Daí surgiu o termo "construtivismo" - embora esse termo nunca tenha sido utilizado por Piaget; para além disso, Piaget jamais se ocupou de assuntos relacionados ao ensino, em geral, ou à alfabetização, em particular.

O equívoco fundamental de Emília Ferreiro reside em pressupor - com base em um único estudo realizado com 13 crianças de classe média alta na Argentina - a existência de estágios inatos a partir dos quais as crianças, em contato com o texto escrito, isto é, com o ambiente, seriam capazes de "construir" seu conhecimento da leitura, ou seja, tal qual Champolion, seriam capazes de descobrir o segredo da pedra Roseta, ou seja, as regras arbitrárias do Sistema Alfabético de Escrita de suas respectivas línguas. Assim, se Kenneth Goodman já tinha feito um salto conceitual com bases duvidosas, afirmando que a leitura poderia ser adquirida de forma tão natural como a fala, Emília Ferreiro ainda vai mais longe, ao propor que a escrita poderia também seguir essa via "natural" de aquisição.

O uso de evidências empíricas frágeis é comum na ciência, sobretudo entre cientistas mais voltados para o uso aplicado de conceitos e resultados científicos. Há inúmeros vieses introduzidos no pensamento e nas práticas científicas - inclusive nos jornais científicos. $\mathrm{O}$ 
edifício da ciência não é exatamente uma catedral de virtudes. O edifício tem portas e janelas abertas, por isso teorias e dados são de domínio público e podem ser discutidos, reanalisados e contestados - inclusive à luz de novos métodos de análise.

Já as armadilhas conceituais são mais complexas. Com efeito, a ideia de mecanismos inatos vem sendo reforçada com descobertas da neurociência: os genes são programados não apenas para determinar a estrutura e funcionamento de nossos órgãos físicos, mas também para maximizar a busca de experiências e informações (as chamadas experiências esperadas) que lhes permitem cumprir as suas funções. Por exemplo, somos programados para desenvolver a visão, mas precisamos viver num ambiente com luminosidade para que o nervo ótico se desenvolva. Somos programados para falar, mas dependemos de conviver e interagir com falantes para que possamos adquirir e usar a linguagem.

Sabemos, há pelo menos 20 anos, que animais e crianças nascem e são capazes de computar quantidades pequenas - pombos são capazes de estimar o número de falcões em torno do pombal para avaliar a segurança de sair ou não em busca de alimento, por exemplo (DEHAENE, 2011). Crianças percebem formas, cores e profundidade. No entanto, ninguém se propôs a desenvolver uma "psicogênese da tabuada" ou "psicogênese da geometria" - embora números e formas sejam elementos da natureza - diferentemente da linguagem escrita, que é totalmente arbitrária e inventada.

\subsubsection{ABUSO DE LINGUAGEM}

"Abuso de linguagem, abuso de poder". Este é o título de um magnífico ensaio filosófico de Josef Pieper (1992). Além da ambiguidade, metáforas e analogias - tal como o canto das sereias - constituem um rescaldo preferencial para confundir mentes e difundir ideias equivocadas. Observe como é o uso da linguagem no ataque à alfabetização. $O$ trecho é extraído dos PCNs de Língua Portuguesa (BRASIL, 1997):

É habitual pensar sobre a área de Língua Portuguesa como se ela fosse um foguete de dois estágios: o primeiro para se soltar da Terra e o segundo para navegar no espaço. O primeiro seria o que já se chamou de 'primeiras letras', hoje alfabetização, e o segundo, aí sim, o estudo da língua propriamente dita.

Durante o primeiro estágio, previsto para durar em geral um ano, o professor deveria ensinar o sistema alfabético de escrita (a correspondência fonográfica) e algumas convenções ortográficas do português - o que garantiria ao aluno a possibilidade de ler e escrever por si mesmo, condição para poder disparar o segundo estágio do metafórico foguete. Esse segundo estágio se desenvolveria em duas linhas básicas: os exercícios de redação e os treinos ortográficos e gramaticais.

O conhecimento atualmente disponível (1997) recomenda uma revisão dessa metodologia e aponta para a necessidade de repensar sobre teorias e práticas tão difundidas e estabelecidas, que, para a maioria dos professores, tendem a parecer as únicas possíveis. Por trás da prática em dois estágios, está a teoria que concebe a capacidade de produzir textos como dependente da capacidade de grafá-los de próprio punho (BRASIL, 1997, p. 27). 
Esses trechos poderiam ser analisados linguisticamente de forma isolada e a partir de diferentes perspectivas. Limitamo-nos aos aspectos que parecem mais diabólicos (a palavra diabo significa o que separa, o que divide).

O primeiro parágrafo utiliza uma analogia, a do foguete. Analogias são próprias de terrenos pouco firmes. Analogias, como as metáforas, são sempre imperfeitas - muitas delas acabam sendo falhas. Mas há mais: "o que já se chamou" se refere à tradição secular - senão milenar - de se referir à "alfabetização". Mas, como o texto já sugere, a alfabetização é parte do domínio da terra, dos seres inferiores. O que interessa é alcançar o espaço, o mundo da Língua Portuguesa, que seria o mundo das ideias propriamente ditas. O texto não afirma nada sobre o sujeito - usa o pronome "se" para não se comprometer com as ideias prevalentes. Para completar o registro: o texto também não menciona o abandono das práticas de recitação, leitura oral e das atividades de leitura e o estudo da literatura - que foi abandonado no Brasil a partir do final da década de sessenta, que são práticas que facilitam e potencializam a alfabetização e a literacia.

O segundo parágrafo trata do que seria o mundo real - das práticas seculares de alfabetizar e ensinar a língua - práticas que, de resto, continuam a ser exercitadas na maioria dos países que se utilizam de línguas alfabéticas. A linguagem usada, no entanto, coloca esse mundo real em suspeita - e o uso do tempo ('deveria' - futuro do pretérito do indicativo) revela a intenção do autor. O que o segundo parágrafo não diz é que, nessa caminhada histórica da educação, os professores que eram formados aprendiam a alfabetizar de acordo com os conhecimentos técnicos da época, o livro e a leitura sempre estiveram presentes nas boas escolas, já durante o "primeiro estágio" do foguete. Só que, sabiamente, os livros eram lidos pelos adultos, pois a criança ainda não sabia ler...

O terceiro parágrafo faz duas afirmações que não encontram respaldo na ciência, ao contrário, as evidências já existentes à época (1997) caminham exatamente na direção contrária ao que o texto afirma. Vejamos:

O texto diz que "o conhecimento científico atualmente disponível" recomenda rever essas práticas. Ora, o conhecimento científico disponível em 1997 já demonstrava a importância de alfabetizar as crianças e de usar métodos adequados para isso (nomeadamente os métodos fônicos). O primeiro grande estudo que consolidou essas evidências fora publicado em 1990 por Marilyn Adams e provocara uma onda de estudos, revisões da literatura e meta-análises sobre o tema. Em 1998, a Academia Nacional de Ciências dos Estados Unidos viria a publicar o relatório Preventing Reading Difficulties in Young Children (NATIONAL RESEARCH COUNCIL, 1998), baseado em estudos publicados muitos anos antes de 1997. Poder-se-ia alegar que esses estudos, publicados em língua inglesa, não eram facilmente acessíveis no Brasil. No entanto, mesmo em língua portuguesa, no português do Brasil, estava disponível o livro "A Arte da Leitura" do professor José Morais (1995). Portanto, a afirmação sobre "o conhecimento científico atualmente 
disponível" - ainda mais desprovida de referências bibliográficas - configura-se, novamente, como abuso de linguagem, abuso de poder. Além, obviamente, de equivocada.

Ademais o texto afirma, sem qualquer comprovação, que "Por trás da prática em dois estágios, está a teoria que concebe a capacidade de produzir textos como dependente da capacidade de grafá-los de próprio punho". Ora, no primeiro parágrafo, o termo "os dois estágios" surgia como metáfora. No terceiro, é elevado a uma prática. E, por detrás dessa prática, residiria uma teoria. O texto, no entanto, não documenta nenhuma dessas afirmações - apenas constrói um boneco de palha para poder destruí-lo com um sopro.

\subsubsection{MANIPULAÇÃO DA LINGUAGEM E AS ESTRUTURAS SEMÂNTICAS CORRELATIVAS (... NÃO APENAS..., MAS TAMBÉM...)}

A propagação das ideias do construtivismo foi acompanhada de um competente e articulado uso de formulações linguísticas eivadas de ambiguidades. O conjunto de citações - a maioria delas constantes do documento dos PCNs, salvo se indicado em contrário - fala por si mesmo, os textos grifados ressaltam a manipulação ativa da linguagem para fugir da questão central - alfabetizar as crianças de acordo com as mais robustas recomendações científicas existentes.

\footnotetext{
Alfabetizar não é apenas ensinar códigos de língua escrita, não deve de maneira alguma ser um processo mecânico, hoje não basta apenas saber ler e escrever, mas [também] que se saiba fazer uso da leitura e da escrita (BRASIL, 1997, p.20) (acrescentado pelos autores o texto entre parênteses retos)
}

O parágrafo contém uma série de afirmações sobre as quais nada diz: se alfabetizar não é apenas ensinar os códigos, alfabetizar é (essencialmente) ensinar os códigos. Mas isso não é abordado. A linguagem do "não apenas..., mas também" é usada para mascarar o essencial. Quanto a não ser um "processo mecânico", a afirmação é desprovida de sentido. Até porque uma boa parte dos comportamentos humanos possui uma componente 'mecânica' ou automática, se é que é a isto que o documento se refere. Assim, falar, cantar ópera, dançar balé escrever artigos científicos envolve habilidades reflexas de natureza eminentemente mecânicas ou automatismos: trata-se de uma contingência de nossa natureza humana. E nada nesses "processos mecânicos" ou automatismos Ihes retira a sua natureza intrinsecamente humana.

Enfim, ser alfabetizado não é só ser capaz de juntar letras para formar sílabas, juntar sílabas para formar palavras e palavras para formar frases e frases para formar textos, e sim saber o que está lendo e escrevendo, ter noção de concordância, saber se o que está escrevendo tem coerência; dizer que um sujeito é alfabetizado não é tão simples como parece (BRASIL, 1997, p. 56).

De novo "não é só" ... "e sim". Não é só mas é - e isso precisa ser ensinado. O "e sim" dá um caráter de eliminar o "não é só". Quanto à afirmação: "Dizer que um sujeito é 
alfabetizado não é tão simples como parece" é falsa tanto do ponto de vista empírico (há dezenas de testes de alfabetização no mundo) quanto do ponto de vista conceitual: se sou capaz de definir sou capaz de dizer (ou avaliar).

\begin{abstract}
Progredir alfabetização adentro não é uma jornada tranquila. Encontram-se muitos altos e baixos nesse caminho, cujos significados precisam ser compreendidos. Como qualquer outro conhecimento no domínio cognitivo, é uma aventura excitante, repleta de incertezas, com muitos momentos críticos, nos quais é difícil manter ansiedade sob controle (FERREIRO, 2001, apud GUZZI, 2013, p.5).
\end{abstract}

O leitor deve notar a expressão "alfabetização adentro". A autora dá um cunho épico a uma atividade que, apesar de sua importância como rito de iniciação, é e pode ser realizada de forma lúdica e tranquila com a esmagadora maioria das crianças.

\footnotetext{
Na maioria das vezes as crianças são alfabetizadas na escola, mas a escola vai além do alfabetizar, a escola tem como objetivo formar pessoas leitoras competentes e dar sentido ao ato de ler e escrever, formar sujeitos amantes dos livros, cidadãos alfabetizados e letrados (BRASIL, 1997, p. 59).
}

A afirmação é simplesmente incompreensível. Se a escola faz isso na maioria das vezes (o que não era verdade em 1997 como não é verdade hoje), isso significa que ela sabia alfabetizar, alfabetização era algo não problemático. O resto da frase é ambíguo: "vai além" possivelmente está usado no sentido de "de acordo com a opinião do autor a escola deve ir além". E o resto da frase está usado no sentido de "o autor acha que, pelo fato de alfabetizar, a escola não está formando pessoas leitoras competentes etc.". Ou seja, a linguagem é distorcida no detalhe com o efeito de induzir o leitor a contrapor alfabetização com outros objetivos da escola.

\footnotetext{
Pode se concluir da discussão a respeito do conceito de alfabetização, que essa não é uma habilidade, é um conjunto de habilidades, o que a caracteriza como um fenômeno de natureza complexa, multifacetado. Essa complexidade e multiplicidade de facetas explicam por que o processo de alfabetização tem sido estudado por diferentes profissionais, que privilegiam ora estas ora aquelas habilidades, segundo a área do conhecimento a que pertencem (BRASIL, 1997: 33).
}

Esse último parágrafo condensa em poucas palavras um enorme conjunto de erros de lógica e raciocínio: a. "não é uma habilidade, é um conjunto": mas qual seria o conjunto? Como se chama? A que se refere? b. "um fenômeno de natureza complexa, multifacetado". Qual seria o fenômeno? O alfabeto? O processo? E a complexidade? Quantas faces ou facetas? c. "... explicam porque...” Como assim? O que explica o quê? Um fenômeno complexo pode ser estudado por um profissional só e fenômenos simples podem ser estudados por vários profissionais. d. "Ora privilegiam estas ora aquelas habilidades". Esta afirmação necessita uma análise mais aprofundada.

Fatos são fatos, eles não são disciplinares ou multidisciplinares em si. A ciência se organiza em diferentes campos de conhecimento para tornar possível e manejável a sua observação - sempre provisória - dos fatos que estuda. A alfabetização não é um "fato 
científico", é um fenômeno social que pode e é estudado por diferentes cientistas, com diferentes ênfases. Isso é natural. Mas isso não exime cada cientista de definir com clareza o objeto do qual ele está falando. O movimento construtivista, especialmente no Brasil, abusa da linguagem exatamente ao não definir o objeto de que está falando. Ao jogar com palavras e definições, impossibilita o engajamento de um diálogo efetivo. Mas tem mais, como veremos no trecho abaixo:

\footnotetext{
O letramento surge sempre envolvido no conceito de alfabetização, o que tem levado a uma interpretação errônea desses dois procedimentos, sendo que o conceito de letramento prevalece sobre o de alfabetização, porém não se podem separar os dois processos (BRASIL, 1997, p.21).
}

O tema do letramento será objeto da Parte II deste artigo, incluímos a citação aqui apenas para indicar mais um trecho do referido documento que se excede na manipulação da linguagem e marca a oficialização do conceito do letramento nas políticas do Ministério da Educação.

\subsubsection{TEXTOS AUTÊNTICOS (DELIMITAÇÃO DE SENTIDO)}

O projeto de desconstrução da alfabetização se origina de duas vertentes. De um lado, ele foi impulsionado pelo surgimento da "genre theory" (no sentido de gêneros literários - não confundir com "gender theory"). A teoria dos gêneros literários foi impulsionada na pedagogia pela chamada "Escola de Sidney", no final dos anos 1970, e teve como protagonista M. Halliday (1978) e reforçou o movimento do "Whole Language".

Tecnicamente falando, o "gênero" constitui as características retóricas do texto e os propósitos semióticos comunicativos a que ele serve. Há discussão entre os linguistas se o "gênero" deve ser tratado como um aspecto do contexto situacional (o registro) ou como um sistema cultural semiótico distinto que se correlaciona com a "tessitura", ou seja, com as três categorias de registro relativas ao campo, tom (tenor) e modo. Halliday associa "gênero" com o modo, mas, consistente com outros estudiosos do tema, defende a ideia de que o "gênero" constitui um sistema semiótico independente por meio do qual se criam e compartilham significados, que se tornam coerentes no âmbito de uma determinada cultura. Esse é o toque de guerra para a difusão do conceito dos "usos sociais da língua".

Dessas ideias surgem inúmeras classificações de gêneros e tipos de texto. Nesse contexto, as tradicionais cartilhas de alfabetização e os textos "decodificáveis" são convertidos em anátema. É assim que surgem, nas determinações relacionadas ao Programa Nacional do Livro Didático - PNLD, afirmações como:

Diretrizes para aprovação de livros didáticos:

A escolha de um texto justifica-se pela qualidade da experiência de leitura que possa propiciar, e não pela possibilidade de exploração de algum conteúdo curricular. Portanto, a 
presença de pseudotextos, criados única e exclusivamente com objetivos didáticos, não se justifica (BRASIL, 1997, p. 43).

Se considerada com rigor, essa definição exclui a possibilidade de publicar qualquer livro didático, pois livros didáticos caracterizam um gênero com um propósito definido: explicar um determinado conteúdo ou aspecto de uma disciplina. Isso também significa que a escola não faria parte da sociedade - a linguagem da escola e de seus instrumentos de trabalho não preenche uma função social. O aluno não pode escrever uma redação para o professor corrigir - isso seria inautêntico - da mesma forma que ensaios de dança e treinos de futebol seriam inautênticos. Em contrapartida, o alvo aqui foram as cartilhas de alfabetização - banidas dos programas oficiais e das escolas desde o final do século passado - e cujas consequências continuam a se observar no desempenho dos alunos brasileiros em atividades de decodificação e de fluência de leitura.

Não se trata aqui de defender esta ou aquela cartilha, muito menos de afirmar que cartilhas sejam essenciais para alfabetizar. Se considerarmos que o contexto da alfabetização é o alfabeto - e não o texto - a rigor não é necessário um texto formal para alfabetizar - como de resto se comprova facilmente, por exemplo, quando a criança se alfabetiza usando softwares. Junto com a água do banho foi o bebê; o setor editorial, aprisionado pelas compras governamentais, deixou de produzir livros e materiais didáticos adequados para alfabetizar as crianças.

O impacto dessas ideias equivocadas persiste até hoje, como se pode observar tanto na BNCC quanto no Edital para aquisição de livros didáticos para anos iniciais, de 2019.

\section{PARTE II - ERROS E CONCEITOS EQUIVOCADOS SOBRE LETRAMENTO E O QUE A CIÊNCIA NOS APRESENTA COMO BONS MÉTODOS DE ALFABETIZAÇÃO}

\subsection{ANATOMIA DE UM CONCEITO}

Nesta seção se baseia inteiramente em considerações feitas pela professora Magda Soares sobre o que, na perspectiva dela, é a alfabetização e o letramento e tem como objetivo apresentar, com a fidelidade possível, o contexto em que se desenvolveram suas propostas.

1 Embora não esteja dentro do escopo do presente trabalho, cabe registrar o risco de deixar nas mãos de um órgão governamental decisões a respeito do que se seja ou não alfabetizar ou de métodos de alfabetização. O risco aumenta quando tais órgãos detêm o monopólio de produção de livros didáticos. Uma comunidade acadêmica ativa e mecanismos plurais de competição parecem mais adequados para fazer florescer a ciência e suas decorrências. 
Como termo moderno em português, letramento foi introduzido por Mary Kato em 1986, no livro "No mundo da escrita: uma perspectiva psicolinguística", ao referir que a língua falada culta é a consequência do letramento (SOARES, 2003). Em 1988, o termo letramento é usado por Leda Verdiani Tfouni no seu livro "Adultos não alfabetizados: o avesso do avesso" (TFOUNI, 1988). O termo é recuperado, em 1995, por Angela Kleiman, no livro "Os significados do letramento", (KLEIMAN, 1995) e por Leda Verdiani Tfouni, no seu livro "Alfabetização e Letramento", (TFOUNI, 2005). Neste último livro, a autora distingue pela primeira vez alfabetização de letramento. Assim, em 1995, o termo letramento entra definitivamente em uso na Educação e na Linguística no Brasil.

Seguindo parte do mesmo percurso que Magda Soares seguiu para definição de conceitos, baseado no Novo Dicionário Aurélio da Língua Portuguesa, alfabetização e letramento são termos do mesmo campo semântico. A alfabetização não é mais que o ato de alfabetizar, isto é, de "ensinar a ler". Assim, alfabetizado é "aquele que sabe ler". Letrado é aquele "versado em letras, erudito" e iletrado é "aquele que não tem conhecimentos literários" a que se acrescenta "o analfabeto ou quase analfabeto".

Magda Soares insiste em acrescentar "e a escrever", quando surge a palavra "ler" relacionada com a alfabetização, pois para ela "ler" e "escrever" são um só pacote conceitual em que a escrita de alguma forma conduz ou orienta a leitura. Por isso, é natural que, para ela,

\footnotetext{
(...) o termo letramento (...) trata-se, sem dúvida, da versão para o Português da palavra da língua inglesa literacy. (...) [que] é o estado ou condição que assume aquele que aprende a ler e a escrever. Implícita nesse conceito está a ideia de que a escrita traz consequências sociais, culturais, políticas, econômicas, cognitivas, linguísticas, quer para o grupo social em que seja introduzida, quer para o indivíduo que aprenda a usá-la². (SOARES, 2003, p. 17)
}

Registra-se que Magda Soares e as autoras que a antecederam escolheram usar 'letramento' como tradução de 'literacy', ao invés de literacia, escolha por exemplo feita em Portugal (CALDEIRA, BOSSLER, no prelo).

Assim, a proposta sobre letramento de Magda Soares considera que a alfabetização e o letramento não são conceitos autônomos, mas sim profundamente inter-relacionados. Idealmente, um não poderá ocorrer sem a presença do outro.

Segundo Magda Soares, dissociar alfabetização e letramento é um equívoco, porque, no quadro das atuais concepções psicológicas, linguísticas e psicolinguísticas de leitura e escrita, a entrada da criança (e também do adulto analfabeto) no mundo da escrita ocorre simultaneamente por esses dois processos: pela aquisição do sistema convencional de escrita - a alfabetização - e pelo desenvolvimento de habilidades de uso desse sistema em

2 De notar que a estrutura e o funcionamento da arquitetura neuronal envolvidos no processamento de leitura e da escrita estão ausentes nesta definição de Magda Soares. 
atividades de leitura e de escrita, nas práticas sociais que envolvem a língua escrita - 0 letramento. (SOARES, 2004, p. 14)

E esse posicionamento torna-se mais compreensível, quando ela esclarece que alfabetização e letramento

\begin{abstract}
Não são processos independentes, mas interdependentes, e indissociáveis: a alfabetização desenvolve-se no contexto de e por meio de práticas sociais de leitura e de escrita, isto é, através de atividades de letramento, e este, por sua vez, só se pode desenvolver no contexto da e por meio da aprendizagem das relações fonema-grafema, isto é, em dependência da alfabetização. (SOARES, 2004, p. 14)
\end{abstract}

O letramento seria assim, o estado ou a condição que adquire um grupo social ou um indivíduo como consequência de ter-se apropriado da escrita e de suas práticas sociais (retirado da tabela sobre LETRAMENTO em SOARES, 2003, p. 32)3.

\title{
2.2. EM BUSCA DE UM MODELO E DE UM MÉTODO
}

Uma vez o termo letramento suficientemente elucidado, cabe perceber em que tipo de modelo esse termo se encaixa. Uma vez percorrida essa etapa, pode-se relacionar termo e modelo com um método aplicável nas salas de aula de alfabetização brasileiras.

Assim, continuando com Magda Soares (2017), o letramento pertence ao campo conceitual do construtivismo, em que se insere a psicogênese da língua escrita de Emília Ferreiro e Ana Teberovsky, e, de certa forma, a concepção holística da aprendizagem da língua escrita, a "Whole Language" de Kenneth Goodman. Estes modelos opõem-se ao modelo fônico, defendido em relatório do National Reading Panel: Teaching Children to Read, do ano de 2000. Nesse relatório, era apresentado um estudo que avaliou e integrou as pesquisas existentes nos Estados Unidos

\footnotetext{
(...) sobre a alfabetização em crianças com o objetivo de identificar procedimentos eficientes para que esse processo se realizasse com sucesso. O subtítulo do relatório esclarece bem sua natureza: (...) uma avaliação baseada em evidências da literatura da pesquisa científica sobre a alfabetização e suas implicações para a instrução ${ }^{4}$ (SOARES, 2017, p. 43).
}

Esse relatório, que teve um impacto profundo sobre a pesquisa em alfabetização e literacia, mas não, como já vimos, na formação inicial de professores alfabetizadores no Brasil, concluiu que

3 Esta definição de letramento é usada abundantemente em publicações acadêmicas no Brasil, mas não de outros países (CALDEIRA e BOSSLER, no prelo), que, costumeiramente, fazem uso da palavra e do conceito literacia.

4 Curiosamente, o que levanta suspeitas em Magda Soares sobre a natureza do relatório é que ele visava desenvolver recomendações para a instrução, isto é, para o ensino explícito, direto e sistemático, algo que ela e os autores que se socorrem do letramento consideram a pior forma de ensino, preferindo formas de ensino nas quais o aluno possui aparentemente um papel mais ativo, contrariando as melhores evidências científicas (ENKVIST, 2020; STOCKARD, WOOD, COUGHLIN e KHOURI, 2018 - este último envolvendo 328 estudos e quase 4 mil efeitos). 
(...) entre as facetas consideradas componentes essenciais do processo de alfabetização consciência fonêmica, phonics, (relações fonema-grafema), fluência em leitura (oral e silenciosa), vocabulário e compreensão -, as evidências a que as pesquisas conduziam mostravam que têm implicações altamente positivas para a aprendizagem da língua escrita o desenvolvimento da consciência fonêmica e o ensino explícito, direto e sistemático das correspondências fonema-grafema (SOARES, 2017, p. 43).

Assim, como sublinha a autora, a concepção da língua escrita presente nesse relatório é mais ampla que apenas e só a aprendizagem do código e da correspondência sistemática fonema-grafema, por ela designada por relações fonema-grafema, e que essa aprendizagem deveria ser apoiada através de ensino direto, explícito e sistemático (SOARES, 2017).

Esse posicionamento significaria um movimento de retrocesso, de retorno às concepções tradicionais de alfabetização, segundo Magda Soares, pois seria a volta ao fônico "(...) como se, para endireitar a vara, fosse mesmo necessário curvá-la para o lado oposto, ou como se o pêndulo devesse estar ou de um lado ou de outro. É essa tendência a radicalismos que torna perigosa e necessária reinvenção da alfabetização5" (SOARES, 2017, p. 44).

E esse retrocesso poderia ocorrer opondo, de um lado, a concepção holística da aprendizagem da língua escrita da "Whole Language" e o construtivismo proposto por Emília Ferreiro e Ana Teberovsky na sua psicogênese da língua escrita ao método fônico, proposto no estudo da National Reading Panel, do outro. Segundo Magda Soares (2017), o antagonismo entre as primeiras e o último é sobretudo político e não conceitual, pois a concepção holística e o construtivismo "(...) consideram a aprendizagem das relações grafofônicas como parte integrante da aprendizagem da língua escrita - ocorreria a alguém a possibilidade de se ter acesso à cultura escrita sem a aprendizagem das relações entre o sistema fonológico e o sistema alfabético?” (SOARES, 2017, p. 44).

A grande diferença entre os métodos de alfabetização baseados no construtivismo e o método fônico de alfabetização reside no papel que é dado ao ensino, tendencialmente ausente nos primeiros e central no segundo, e naquilo que Magda Soares considera ser o melhor formato para a aprendizagem da leitura (e da escrita). Enquanto as abordagens fônicas entendem que o desenvolvimento das relações fonema-grafema se deve apoiar em processos de ensino explícito, direto e sistemático,

(...) com certa autonomia em relação ao desenvolvimento de práticas de leitura e escrita, [para a concepção holística e a abordagem construtivista] essas relações não constituem propriamente objeto de ensino, pois sua aprendizagem deve ser incidental, implícita, assistemática, no pressuposto de que a criança é capaz de descobrir por si mesma as relações fonema-grafema, em sua interação com material escrito e por meio de experiências com

5 O uso da palavra 'radicalismos' não é inocente: classificando o fônico como método radical torna-se desnecessário analisá-lo e identificar as potencialidades desse método face a outros métodos. Mais, ao salientar o fônico, um dos cinco componentes considerados essenciais no processo de alfabetização, toma-se a floresta pela árvore e deita-se fora o bebê junto com a água do banho! 
práticas de leitura e escrita. Pode-se, talvez, dizer que, no primeiro caso, privilegia-se a alfabetização, no segundo caso, o letramento. O problema é que, num e noutro caso, dissocia-se equivocamente alfabetização de letramento, e, no segundo caso, atua-se como se realmente pudesse ocorrer de forma incidental e natural a aprendizagem de objetos de conhecimento que são convencionais e, em parte significativa, arbitrários - o sistema alfabético e o sistema ortográfico (SOARES, 2017, p. 44).

Assim, para Magda Soares (2017), é essencial diferenciar entre alfabetização e letramento, mesmo tendo em atenção que um e outro são indissociáveis.

(...) os equívocos (...) anteriormente mencionados levaram alfabetização e letramento a se confundirem, com prevalência deste último e perda da especificidade da primeira, o que se constitui como uma das causas do fracasso em alfabetização que hoje ainda se verifica nas escolas brasileiras, a distinção entre os dois processos e consequente recuperação da especificidade da alfabetização tornam-se metodológica e até politicamente convenientes, desde que essa distinção e a especificidade da alfabetização não sejam entendidas como independência de um processo em relação ao outro, ou como precedência de um em relação ao outro.

(...) talvez reconhecer a possibilidade e mesmo a necessidade de estabelecer a distinção entre o que mais propriamente se denomina letramento, de que são muitas as facetas - imersão das crianças na cultura escrita, participação em experiências variadas com a leitura e a escrita, conhecimento e interação com diferentes tipos e gêneros de material escrito - e o que é propriamente a alfabetização, de que também são muitas as facetas - consciência fonológica e fonêmica, identificação das relações fonema-grafema, habilidades de codificação e decodificação da língua escrita, conhecimento e reconhecimento dos processos de tradução da forma sonora da fala para a forma gráfica da escrita (SOARES, 2017, p. 45-46).

Deste modo, encontra-se aberta a vereda para se usarem métodos falhos de alfabetização/letramento nas salas de aula brasileiras, principalmente pelo não entendimento das estruturas neuroanatômicas que se encontram envolvidas nos processos de leitura e que o método fônico ativo, obtendo bons resultados em termos de alfabetização e de literacia.

Entretanto, é preciso não ter medo do método ${ }^{6}$. Diante do assustador fracasso escolar na área da alfabetização e, considerando as condições atuais de formação do professor alfabetizador em nosso país, estamos, sim, em busca de um método, para que tenhamos a coragem de afirmá-lo. Porém, precisa-se de um método no conceito verdadeiro desse termo: método que seja o resultado de determinação clara de objetivos definidores dos conceitos, das habilidades e das atitudes, que caracterizam a pessoa alfabetizada, numa perspectiva psicológica, linguística e, também (e, talvez, sobretudo - segundo Magda Soares), social e política.

Nessa perspectiva, necessita-se que o método seja ainda o resultado da opção pelos paradigmas conceituais (psicológico, linguístico e pedagógico), que trouxeram uma nova concepção dos processos de aprendizagem da língua escrita pela criança, compreendendo esta como sujeito ativo que constrói o conhecimento, e não ser passivo que responde a estímulos externos. Enfim, um método que seja o resultado de ações, de procedimentos

6 Esse medo incensado por Magda Soares talvez se deva à associação que ela eventualmente poderá fazer entre método e regras desse método, com a aplicação mecânica dessas regras, tão criticada por ela em relação aos por ela designados "métodos tradicionais". 
e de técnicas compatíveis com esses objetivos e com essa opção teórica (SOARES, 2017, p. 127-128 - sublinhado dos autores).

No entanto, apesar do apelo a diferentes campos científicos que poderão ser aduzidos na pesquisa para melhor se compreender os processos de alfabetização, Magda Soares não nomeia as neurociências, a neuropsicologia ou mesmo as ciências cognitivas, que deram contributos decisivos para compreendermos o que resulta e não resulta nos processos de alfabetização e que métodos de alfabetização são mais efetivos e quais os que desafiam e derrotam os alunos, impedindo-os muitas vezes de se alfabetizarem (CALDEIRA, BOSSLER, no prelo).

\subsection{COMENTÁRIOS SOBRE A PROPOSTA DE LETRAMENTO APRESENTADA}

Cabe notar que Magda Soares, mesmo quando aborda as questões da alfabetização, escreve sempre "aprendizagem da língua escrita" e não "aprendizagem da leitura". A leitura para ela está sempre subordinada à escrita, pelo que a autora não reconhece a diferença entre "Aprender a Ler" e "Ler para Aprender".

No entanto, nossa perspectiva acerca do "ler" e do "escrever" centra-se no fato de que são fenômenos autônomos, em que a aprendizagem da leitura necessariamente precede a aprendizagem da escrita. A primeira é mais fácil que a segunda (DEHAENE, 2020). Em termos de aprendizagem, a primeira precede a segunda. Mais, o cérebro lê letras. Como José Morais (apudOLIVEIRA, 2005, p. 19) nos esclarece "Há redes neuronais específicas para o tratamento das letras - diferentemente de números, desenhos ou do sentido das palavras".

Magda Soares foge do "ensino explícito, direto e sistemático" como o Diabo foge da cruz, sem explicitar muito bem porque se deve evitar o ensino direto, o qual trouxe bons resultados na alfabetização de bilhões de alunos ao longo da história em todo mundo. Por que enfatizar as inferências? Parece haver uma crença, sustentada na abordagem psicogenética da língua escrita de Emília Ferreiro, de que o "ensino direto, explícito e sistemático" automaticamente transforma o aluno em sujeito passivo em seus próprios processos de aprendizagem e que as inferências propostas por Magda Soares o transformam em sujeito ativo.

Magda Soares e, por inerência, todos os autores que apoiam e contribuem para o letramento em termos conceituais, esqueceram-se de um pequeno pormenor quando propõem que quem está a aprender a ler deve ser considerado em sua inteireza como ser e, decorrente disso, deve ser visto como um sujeito ativo que constrói o conhecimento, e não ser passivo que responde a estímulos externos. A metáfora usada, o de construtor de conhecimento, é banal e ruim, remetendo para um conceito de 'ativo' em termos físicos, observável, visível. No entanto, a 'construção' de conhecimento não é um processo visível a olho nu, mas podemos ter acesso a esse processo de 
'construção' através de algumas técnicas atualmente disponíveis, como por exemplo, entre outras, de tomografia computacional.

Torna-se evidente, portanto, que o letramento como termo é sofrível e como conceito não é científico. Claramente, é uma teoria (pseudo)científica que se esqueceu de ter em consideração a estrutura e o funcionamento neuro anatômico nos processos de leitura e de aprendizagem da leitura.

\subsection{O QUE AS NEUROCIÊNCIAS NOS ENSINAM SOBRE ALFABETIZAÇÃO E MÉTODOS DE ALFABETIZAÇÃO}

Desde o século XIX que o mapeamento funcional neuro anatômico de processos associados à linguagem, como a fala ou a leitura, consistentemente nos indica que eles são, genericamente, processados em diversas localizações do hemisfério esquerdo do cérebro. Todos os autores atuais das neurociências, da neuro educação e da psicologia cognitiva são unânimes em afirmar que os bons processos de alfabetização são aqueles cujos métodos implicam a atuação de estruturas neuroanatômicas localizadas no hemisfério esquerdo do cérebro (DEHAENE, 2020).

Assim, a análise da localização neuro anatômica em que ocorre o processamento dos estímulos associados à alfabetização pelos principais métodos de alfabetização (fônico versus global, por exemplo) é fundamental para entendermos porque um deles é melhor do que outro e porque um deles, de fato, dificulta a aprendizagem da leitura e, consequentemente, da escrita.

Ao método fônico, os autores das neurociências associam o que se centra no estabelecimento de correspondências sistemáticas entre fonemas e grafemas, por isso também é conhecido por método grafema-fonema (método GF). O método global, que decorre de modelos como a concepção holística da aprendizagem da língua escrita (Whole Language) ou baseados na psicogênese da língua escrita de Emília Ferreiro e Ana Teberovsky, partem da palavra escrita e dos usos sociais da língua escrita (SOARES, 2003) para a aprendizagem da leitura e da escrita.

O estudo do impacto neuronal desses métodos e da sua efetividade na aprendizagem da leitura iniciou-se nos anos finais do século XX (MCCANDLISS; SCHNEIDER; SMITH, 1997), mas, somente em 2010, depois de quase uma década para o desenvolvimento de estímulos culturalmente neutros, que poderiam ser diretamente associados ao método GF ou ao método global de aprendizagem da língua escrita (ver, por exemplo, MCCANDLISS; COHEN; DEHAENE, 2003), começou a ficar explícita a superioridade do método GF sobre o método global na aprendizagem da língua escrita (YONCHEVA; BLAU; MAURER; MCCANDLISS, 2010). 
Nesse estudo, foram usados símbolos fusiformes que representavam letras. Esses símbolos agrupavam-se em blocos de três, formando palavras em inglês de três letras (ver Figura 1).

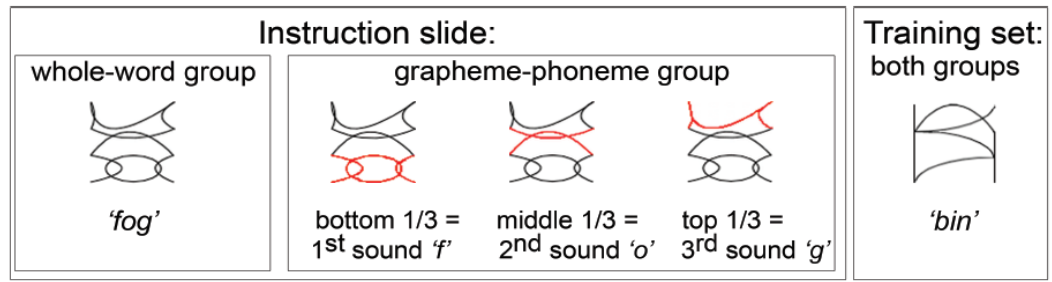

Figura 1. Slide de instrução. (Fonte: YONCHEVA et al., 2010).

$\mathrm{Na}$ esquerda, é apresentada a versão fusiforme da palavra 'fog' (três letras, apresentadas em coluna, lendo-se debaixo para cima), ao centro é apresentada a decomposição da palavra 'fog' - embaixo a letra correspondente ao som 'f', ao meio a letra correspondente ao som 'o' e em cima a letra correspondente ao som ' $g$ ' e à direita o conjunto de treino para os dois grupos de participantes (YONCHEVA et al., 2010).

Foram constituídos dois grupos experimentais com adultos letrados e sem problemas de visão, todos destros. Ao primeiro grupo era apenas mostrada a palavra ('bin', no treino, depois 'fog' e outras palavras). Ao segundo grupo era mostrada a palavra e fazia-se a respectiva decomposição, tal como é apresentado na Figura 1.

Em seguida, através de testagens individuais, eram apresentados sequencialmente diversos estímulos (símbolos fusiformes) para que os sujeitos decifrassem as palavras. De início, os sujeitos submetidos ao 'método global' saiam-se melhor que os sujeitos submetidos ao 'método GF'. No entanto, à medida que mais estímulos eram apresentados, os sujeitos do 'método GF' saiam-se muito melhor que os sujeitos do 'método global'. No final, estes últimos tinham um desempenho semelhante a quem apenas tentasse adivinhar as palavras correspondentes aos símbolos apresentados.

Assim, se no início da aprendizagem de um novo código de escrita, se usar um ou outro método de ensino não tem impacto na aprendizagem, com o acumular de símbolos a aprender (relembrando que no método global cada palavra é um símbolo e no método GF cada 'letra' é um símbolo), o método global se apresenta como uma barreira a uma aprendizagem efetiva da leitura. Por quê?

Essa última questão foi resolvida por uma equipe de pesquisadores de universidades francesa, belga e luxemburguesa (DE GHELCKE; ROSSION; SCHILTZ; LOCHY, 2018; 2019), que estudaram a localização cerebral do processamento de palavras na aprendizagem da leitura em alunos iniciantes, comparando o método GF com o método global ou com um método misto.

Na comparação entre o método GF e o método global, os alunos iniciantes saem-se melhor com o método GF do que com o método global. Por quê? Porque o processamento 
de letras e a correspondência grafema-fonema ocorre no hemisfério esquerdo do cérebro, isto é, onde se localizam as áreas cerebrais especializadas no processamento da língua escrita. Por outro lado, o processamento de palavras como um todo a ler, como pressupõe o método global, ocorre em iniciantes da leitura no hemisfério direito, onde se localizam as áreas cerebrais especializadas no processamento de imagens (DE GHELCKE; ROSSION; SCHILTZ; LOCHY, 2018).

E o que ocorre quando o método é uma combinação de GF e global, como o sugerido por Magda Soares (2017)? Feita a comparação do método GF com um método misto verificou-se, mais uma vez, que o método GF é mais efetivo para o ensino da leitura. Por quê? Porque, analisando impactos neuro anatômicos, verificou-se que o uso do método misto ativa áreas nos dois hemisférios cerebrais: algumas áreas do hemisfério esquerdo especializadas no processamento da língua escrita e, em simultâneo, algumas áreas do hemisfério direito, especializadas no processamento de imagens.

Assim, o uso do método global ou de métodos mistos em alfabetização em detrimento do método GF é equivocado e conduz a resultados de aprendizagem da leitura desastrosos. Resultados que depois se revelam muito difíceis de reverter. Esses métodos contribuem para aprendizagens deficientes da leitura com especial impacto nas crianças cujas famílias não têm hábitos regulares de leitura e de classes sociais economicamente mais frágeis. ${ }^{7}$

\section{CONCLUSÕES}

As duas grandes fontes de erros e equívocos que impactaram negativamente os processos de alfabetização em uma boa parte dos países do Mundo, em particular na América Latina, foram a "Whole Language", inicialmente desenvolvida por Kenneth Goodman e aplicada aos processos educativos por Frank Smith, que propunha que a aprendizagem da leitura deveria ser considerada um processo tão natural como aprender a falar, e o socio construtivismo de Emília Ferreiro, que estendia essa 'naturalidade' do aprender a falar para o aprender a escrever.

Essas naturalizações do aprender a ler e do aprender a escrever, equivalendo-os ao aprender a falar, constituem erros conceituais profundos, pois, enquanto a aprendizagem da fala é de fato algo que ocorre naturalmente durante os primeiros anos de vida,

7 E em relação aos sujeitos em que o hemisfério direito é predominante no processamento da linguagem, poder-seá questionar o leitor. Basta tomar em consideração que, nesses sujeitos, o método fônico ativa sobretudo as áreas do hemisfério direito associadas à linguagem e os métodos global e misto ativam sobretudo as áreas do hemisfério esquerdo alocadas ao processamento de imagens. O problema permanece! 
socorrendo-se a criança apenas de seu contexto social e das trocas linguísticas que estabelece com outros seres humanos da sua comunidade linguística para fazer essa aprendizagem, aprender a ler e a escrever são tarefas artificiais: exigem aprendizagem sistemática em processos que são necessariamente mecânicos.

Acresce que o sócio construtivismo, no Brasil, tomou os espaços políticos, isto é, os espaços onde se decidem as políticas públicas relacionadas com a alfabetização e o letramento, e a academia, tornando-se hegemônica nos espaços de formação dos professores alfabetizadores e nos espaços de divulgação técnica e 'científica'. No entanto, essa hegemonia em termos políticos e acadêmicos não foi acompanhada de estudos e de pesquisas que provassem definitivamente que as propostas apresentadas em documentos oficiais, que os programas de alfabetização ou que os planos de alfabetização desenvolvidos por décadas no Brasil se socorriam de métodos efetivos de alfabetização, isto é, de métodos que proporcionassem bons processos de alfabetização às crianças brasileiras.

Antes pelo contrário, essa hegemonia baseou-se em pura ideologia sem comprovação científica. Assim, usando linguagem abusiva, sem preocupação de justificar suas crenças, os autores que escreveram ou influenciaram documentos oficiais que contestaram livros didáticos de alfabetização por não usarem "textos autênticos", não percebendo que com isso: a. condenavam todos os textos didático-pedagógicos especificamente desenvolvidos para auxiliarem as aprendizagens dos alunos, b. criticaram os processos "mecânicos de alfabetização" ou; c. se preocupam com as elevadas taxas de analfabetismo funcional e de dificuldades de aprendizagem das "primeiras letras". Esses autores propuseram o aprofundamento de métodos diferenciados, sobretudo que não se relacionassem com os formatos tradicionais de alfabetização, demonstrando deste modo que não compreenderam que é a própria metodologia que propõem que derrota os alunos e que insistir no uso dessa metodologia resulta no aprofundar do problema.

Por que os problemas com a alfabetização, então, se agravam no Brasil? Um único fato explica isso: nas salas de aula de alfabetização são sobretudo usados métodos de alfabetização equivocados. Esses métodos dificultam a alfabetização de muitas crianças, especialmente as que têm famílias que em casa não possuem hábitos de leituras. Por quê? Porque esses métodos de alfabetização, os globais ou os mistos, não estimulam de forma sistemática as áreas cerebrais especializadas no processamento da leitura e da escrita, que em geral se localizam no hemisfério cerebral esquerdo, pois estimulam sobretudo ou exclusivamente áreas cerebrais especializadas no processamento de informação visual e de imagens, que em geral se localizam no hemisfério cerebral direito. $O$ único método, ou antes, o conjunto de métodos de alfabetização que estimulam as áreas cerebrais especializadas no processamento da leitura e escrita são os fônicos. 


\section{REFERÊNCIAS}

ACADEMIA BRASILEIRA DE CIÊNCIAS. 2009. Grupo de Trabalho sobre Educação Infantil. Rio de Janeiro: Academia Brasileira de Ciências.

ADAMS, M. J. Beginning to read: Thinking and learning about print. Cambridge, MA: MIT Press, 1990.

ADLER, Mortimer. Ten philosophical mistakes. New York: MacMillan Publ. Co, 1985.

ANDRADE, Paulo Estevão, ANDRADE, Olga Valéria Campa dos Anjos, PRADO, Paulo Sérgio T. do. Psicogênese da Língua Escrita: Uma Análise Necessária. Cadernos de Pesquisa v.47 n.166 p.1416-1439, out./dez. 2017. Disponível em https://www.researchgate.net/publication/321757485_Psicogenese_da_lingua_escrita_uma_analise_necessaria. Acesso em jun. 2020

BARKE, Hans-Dieter, HAZARI, Al., YITBAREK, S. Misconceptions in Chemistry: Addressing Perceptions in Chemical Education. Berlin-Heidelberg: Springer-Verlag, 2009.

BRASIL. Ministério da Educação. PNAIC - Plano Nacional de Alfabetização na ldade Certa. Documento Orientador PNAIC em Ação 2017. Brasília, 2017. Disponível em

http://pacto.mec.gov.br/images/pdf/doc_orientador/doc_orientador_versao_final.pdf. Acesso em 14 jun. 2020.

BRASIL. Ministério da Educação. BNCC - Base Nacional Comum Curricular. Brasília: 2018. Disponível em http://basenacionalcomum.mec.goc.br. Acesso em jun. 2020.

BRASIL. Secretaria de Educação Fundamental. Parâmetros curriculares nacionais: língua portuguesa. Brasília: 1997.

BRUNER, J. On learning mathematics. Mathematics Teacher, 88 (4), p. 330-335, 1995.

CALDEIRA, Pedro Zany, BOSSLER, Ana Paula. Liberdade para aprender a ler e a escrever. desesquerdizando a alfabetização brasileira. No prelo. Edição dos autores.

CAREY, S., EVANS, R., HONDA, M., JAY, E., UNGER, C. An experiment is when you try it and see if it works: A study of grade 7th students' understanding of the construction of scientific knowledge. International Journal in Science Education, 11, p. 514-529, 1989.

CHI, M. T. H. Three types of conceptual change: belief revision, mental model transformation and categorical shift In. VOSNIADOU, S. (ed.). Handbook of research in conceptual change. Nova lorque e Londres: Routledge Taylor \& Francis Group, 2008, p. 61-82.

CHINN, C., BREWER, W. The role of anomalous data in knowledge acquisition: A framework and implications for Science instruction. Review of Educational research, 63 (1) 1-49, 1993.

DE GHELCKE, Alice van de Walle, ROSSION, Bruno, SCHILTZ, Christine, LOCHY, Aliette. Teaching methods shape neural tuning to visual words in beginning readers. BiorXiv, outubro, 2018. Disponível em https://www.biorxiv.org/content/10.1101/446203v1.full. Acesso em 30 mai. 2020.

DE GHELCKE, Alice van de Walle, ROSSION, Bruno, SCHILTZ, Christine, LOCHY, Aliette. Impact of Learning to Read in a Mixed Approach on Neural Tuning to Words in Beginning Readers. Frontiers in Psychology, 10: 3043, 2019. Disponível em https://www.ncbi.nlm.nih.gov/pmc/articles/PMC6989560/. Acesso em 30 mai. 2020.

DEHAENE, Stanislas. Number Sense. New York: Oxford Press, 2011, p. xiii-xxv.

DEHAENE, Stanislas. Neurônios da Leitura. Porto Alegre: Artes Médias, 2012.

DEHAENE, Stanislas. How We Learn: Why Brains Learn Better Than Any Machine ... for Now. Nova York: Viking, 2020.

DISESSA, A. Towards an epistemology of physics, Cognition and Instruction, $n^{\circ} 10$ (2-3): p. 105-225, 1993. doi: 10.1207/s1532690xci1002\&3_2

DRIVER, R. The pupil as scientist? Open University Press: Maidenhead, 2008.

DRIVER, R., SQUIRES, A., RUSHWORTH, P., WOOD-ROBINSON, V. Making Sense of Secondary Science: Research into Children's Ideas. London: Routledge, 1994. 
ENKVIST, Inge. A Boa e a Má Educação: Experiências Internacionais. São Paulo: Kirion, 2020.

FERREIRO, E. e TEBEROSKY, A. Psicogênese da língua escrita. Tradução de Diana M. Linchestein et al. Porto Alegre: Artes Médicas, 1985

GAUTHIER, C., BISSONNETTE, S \& RICHARD, M. Sucesso acadêmico e reformas educativas. In Oliveira, J. (org.) Profissão professor: o que funciona em sala de aula. Rio de Janeiro: Instituto Alfa e Beto, 2010, p. 30-47

GOODMAN, Kenneth S. What's Whole in Whole Language?Portsmouth, NH: Heinemann, 1986.

GOMBERT, J. E. Atividades metalinguísticas e aprendizagem da leitura. In M. R. Maluf (Org.) Metalinguagem e aquisição da escrita. Contribuições da pesquisa para a prática da alfabetização. São Paulo: Casa do Psicólogo, 2003, p.19-63.

HALLIDAY, M. A. K. Language as social semiotic: The social interpretation of language and meaning. London: Edward Arnold, 1978.

KATO, Mary. No mundo da escrita: uma perspectiva psicolinguística. São Paulo: Ática, 1986.

KLEIMAN, Ângela. Os significados do letramento: uma nova perspectiva sobre a prática social da escrita. Campinas: Mercado da Letras, 1995.

KHUN, Thomas. A Estrutura das Revoluções Científicas. 13. ed. São Paulo: Perspectiva, 2017. 323 p.

KOLINSKY, R. e MORAIS, J. The worries of wearing literate glasses. L'Année Psycologique/Topics. In Cognitive Psychology, n 118, p. 321-347, 2014. doi: org/10.1016/i.tine.2014.08.001

MCCANDLISS, B. D., BECK, I. L., SANDAK, R., PERFETTI, C. A. Focusing attention on decoding for children with poor reading skills: Design and preliminary tests of the word building intervention. In Scientific Studies of Reading, 7, 75104,2003

MCCANDLISS, B. D., COHEN, L., DEHAENE, S. The visual word form area: Expertise for reading in the fusiform gyrus. In Trends in Cognitive Sciences, 7, 293-299, 2003.

MCCANDLISS, B. D., SCHNEIDER, W., SMITH, T. Learning to read new visual symbols as integrated wholes or component parts. In 38th Annual Meeting of the Psychonomic Society, 1997, Anais.

MINSTRELL, J. Facets of students' knowledge and relevant instruction. In. DUIT, R.; Goldberg, F. \& ZNEIDDERER, H. (Eds.). Research in psychics learning. Theoretical issues and empirical studies. Kiel, Alemanha, IPN, 1992.

MORAIS, José. Alfabetizar para a democracia. Porto Alegre: Penso, 2014.

MORAIS, José. A Arte de Ler. São Paulo: Fundação Editora UNESP, 1995.

MORAIS, J. e KOLINSKY, R. Seeing thought: a cultural cognitive tool. In J. Cult. Cogn Sci, 2020. doi: org/10.1007/s41809=020-00059-0. Disponível em https://link.springer.com/article/10.1007/s41809-020-00059-0 Acesso em jun. 2020.

NATIONAL READING PANEL. Teaching Children To Read, 2000. Disponível em https://www.nichd.nih.gov/sites/default/files/publications/pubs/nrp/Documents/report.pdf. Acesso em jun. 2020.

NATIONAL RESEARCH COUNCIL. Preventing Reading Difficulties in Young Children. Washington, DC: The National Academies Press, 1998. https://doi.org/10.17226/6023.

O’SHAUGNESSY, M. P. Errors and expectations. Nova lorque: Oxford University Press, 1977.

OHLSSON, S. Meaning change, multiple routes, and the role of differentiation in conceptual change: alternative to resubsumption. Educational Psychologist, 44 (1), 64-71, 2009.

OLIVEIRA, João Batista Araujo (org.). Fraturas na Base: Fragilidades estruturais da BNCC - a Base Nacional Curricular Comum. Brasília, DF: Instituto Alfa e Beto, 2018.

OLIVEIRA, João Batista Araujo (org.). O ensino da matemática nas séries iniciais. Rio de Janeiro: Instituto Alfa e Beto, 2012, p. $15-46$. 
OLIVEIRA, Joao Batista Araujo. Alfabetização de crianças e adultos: novos parâmetros, $2^{\mathrm{a}}$ ed. Belo Horizonte: Alfa Educativa, 2005

PERFETTI, Charles A., VAN DYCK, Julie, HART, Lesley. The Psycholinguistics of Basic Literacy. Annual Review of Applied Linguistics, 21, 127-149, 2001.

PIEPER, Josef. Abuse of language, abuse or power. São Francisco: Ignatius Press, 1992.

Annual Review of Applied Linguistics (2001) 21, 127-149. Printed in the USA.

POPPER, K. A lógica da pesquisa científica. São Paulo, Cultrix, 1993.

SADLER, P.M., SONNERT, G., COYLE, H.P., COOK-SMITH, N., MILLER, K.L. Student learning in middle school science classrooms. American Educational Research Journal, 50, 1020-1049, 2013.

SCHON, D. Displacement of concepts. London: Tavistock, 1963.

SEIDENBERG, Mark. Language at the Speed of Sight: How to Read, Why So Many Can't and What Can Be Done About It. Nova York: Basic Books, 2017 (edição eletrônica sem referência a páginas)

SMITH, Frank. Compreendendo a Leitura: Uma Análise Psicolinguística da Leitura e do Aprender a Ler. Porto Alegre, RS: Artmed, 2003

SNYDER, I. Literacy Wars. Why teaching children to read and write is a battleground in Australia? Crows Nest NSW: Allen \& Unwin, 2008.

SOARES, Magda. Letramento: um tema em três gêneros. Belo Horizonte: Autêntica, 2003. 128 p.

SOARES, Magda. Letramento: as muitas facetas. Revista Brasileira de Educação, jan. / fev. / mar. / abr. № 25, 5-17, 2004.

SOARES, Magda. Alfabetização e Letramento. $7^{\mathrm{a}}$ ed. São Paulo: Contexto, 2017. 192 p.

STANOVICH, Keith E. Matthew. Effects in Reading. Some Consequences of Individual Differences in the Acquisition of Literacy, Reading Research Quarterly, 21 (4), 360-407, 1986.

STOCKARD, Jean, WOOD, Timothy W., COUGHLIN, Cristy, KHOURI, Caitlin Rasplica. The Effectiveness of Direct Instruction Curricula. A Meta-Analysis of a Half Century of Research. Review of Educational Research, 88 (4), p..479507,2018

TALANQUER, V. Explanations and Teleology in Chemistry Education. International Journal of Science Education, 29 (7), p. 853-870, 2007.

TFOUNI, Leda V. Adultos não alfabetizados: o avesso do avesso. Campinas: Pontes, 1988.

TFOUNI, Leda V. Letramento e alfabetização. São Paulo: Cortez, 2005

THOREAU, Henry David. Walden ou A vida nos bosques. Porto Alegre: L\&PM, 2016.

TOMITA, M. K. Examining the influence of formative assessment on conceptual accumulation and conceptual change. Tese de Doutorado, Stanford University, 2008.

VOSNIADOU, S., IONIDES, C., DIMITRAKKOPOLOU, A., PAPAMETRIOU, E. The framework approach to the problem of conceptual change. In. VOSNIADOU, S. (ed.), International Handbook of Research on conceptual change. Nova lorque e Londres: Routledge Taylor and Francis Group, 2001, p. 3-34.

WANDERSEE, J. H., MINTZES, JJ., NOVAK, J.D. Research on alternative conceptions in Science. In D. Gabel (ed.). Handbook of research in Science Teaching and learning. Nova Yorque: McMillan, 1994, p. 177-210.

YIP, D. Teachers' Misconceptions of the circulatory system. Journal of Biological Education, 32, 207-215, 1998.

YONCHEVA, Yuliya N., BLAU, Vera C., MAURER, Urs, MCCANDLISS Bruce D. Attentional Focus During Learning Impacts N170 ERP Responses to an Artificial Script. Developmental Neuropsychology, 35, 4, 423-445, 2010. 